\title{
INFLUENCE OF INORGANIC AND ORGANIC DIETARY ZINC ON ITS CONCENTRATION IN BLOOD SERUM, BONES AND HAIR AND ON CATALYTICAL ACTIVITY OF SOME SERUM ENZYMES IN PIGS
}

\author{
V. RUPIC ${ }^{1}$, L. IVANDIJA ${ }^{2}$, S. LUTEROTTI ${ }^{3}$, M. DOMINIS-KRAMARIC' \\ ${ }^{1}$ Faculty of Agriculture, University of Zagreb. Zagreb. Croatia; 'PLIVA, Chemical and Pharmaceutical Works, \\ Research and Development, Zagreb, Croatia; and ${ }^{3}$ Faculty of Pharmacy and Biochemistry, University of Zagreb, \\ Zagreb, Croatia
}

Received October 29, 1996

Accepted June 17, 1997

\begin{abstract}
Rupić, V.. L. Ivandija, S. Luterotti. M. Dominis-Kramarić: Influence of Inorganic and Organic Dietary Zinc on its Concentration in Blood Serum, Bones and Hair, and on Catalytical Activity of Some Serum Enzlmes in Pigs. Acta vet. Brno 1997, 66: 75-85.

The influence of dietary zinc originating from either inorganic or organic source on zincdepleted pigs was investigated. Within the $30 \mathrm{~d}$ period preceding the trial, all the animals (German Landrace $\times$ Piétrain $\times$ Large White $\times$ Swedish Landrace weaned crossbreds) were depleted of zinc and divided into three groups, 14 animals in each. During the experimental fattening period $(105 \mathrm{~d})$, the control group received no extra zinc, whereas the two trial groups were fed a diet with zinc supplement either as inorganic salt $\left(\mathrm{ZnSO}_{4}\right)$ or metalo-organic chelate (zinc methionate). On average, the respective supplements contained $84.3 \mathrm{mg} \mathrm{Zn.kg}{ }^{-1}$ diet and $40.9 \mathrm{mg} \mathrm{Zn.kg}{ }^{-1}$ diet.

Evaluation of the nutritional effects of zinc was based on its concentration in the blood serum, bone and hair. Moreover, the effect of zinc on catalytical activity of alkaline phosphatase. aspartate aminotransferase, alanine aminotransferase and gamma-glutamyltransferase in serum was studied. A decrease of catalytical activity of both aspartate aminotransferase and alanine aminotransferase was found along with signs of parakeratosis on the skin of control animals but no correlation with serum zinc was established. In contrast to this finding. a linear correlation between catalytical activity of alkaline phosphatase and of gamma-glutamyltransferase and serum zinc level was found with the respective correlation coefficients of 0.90 and -0.72 .

Nutritional efficiency of diet zinc was evidenced by both higher $(\mathrm{P}<0.05)$ zinc level in blood serum, bone and hair and by the state of hepatobiliary tract and bones, and favourable performance results of trial animals compared to controls. None of trial animals suffered from any health disturbances. Progressive parakeratosis appeared, however, in control animals and lasted during the second month of the trial. It was accompanied by deterioration of performance data of the affected animals.

Our data suggest that bioavailability of zinc from the chelate was better than of that derived from inorganic salt. particularly in the period of rapid growth. This presumbaly resulted in reduced elimination of zinc. Based on better nutritional efficiency in pigs and on ecological benefits, zinc methionate should be preferred to $\mathrm{ZnSO}_{4}$ as a zinc containing diet additive.
\end{abstract}

Growth, pigs, :inc sulphate. :inc methionate, bioavailability, nutrition

The improvement of body mass gain and carcass quality are among major goals of all pork producers. One of the ways to achieve this is to provide the animals with necessary minerals from the sources of favourable bioavailability. Circulation of zinc and its biological importance in animals (cellular replication, lung tissue $\mathrm{CO}_{2}$ release, sexual maturation, wound healing. fertility and reproduction) have been extensively investigated. Zinc is an essential trace element, and it is an integral part of some 300 enzymes (carbonic anhydrase, alkaline phosphatase, alcohol dehydrogenase, RNA and DNA polymerases, 5-nucleotidase, etc.) which take part in protein synthesis, metabolism of carbohydrates and nucleic acids (Milne 1994). It is assumed that $\mathrm{Zn}$ derived from compounds with amino acids stimulates 
production in animals. Accordingly, Wedekind et al. (1992) pointed to better bioavailability of zinc methionate (ZnMET) compared to that of its inorganic compounds in chickens. Moreover, Herrick (1989) demonstrated an improved body mass gain in fattening cattle by the use of ZnMET in diet. Hartfie ld et al. (1995) brought evidence of increased body mass gain of 6-9\% in weaned lambs supplemented with ZnMET. R u st (1995) and B errie et al. (1994) concluded on improved carcass quality in fattening bullcalves and lambs fed diets with ZnMET. We are particularly interested in the influence of different sources of dietary zinc on performance data and state of health of pigs. There is still no consensus among the investigators considering the bioavailability of inorganic and organic sources of zinc in pigs. Hill et al. (1986) reported on better production results in piglets fed diet with organic zinc, whereas We dek ind et al. (1994) failed to notice such differences.

The aim of our study was to evaluate the bioavailability of diet zinc originating from different chemical sources (inorganic salt and metalo-organic chelate) based on the concentration of zinc in blood serum, bone and hair of growing pigs. As an indicator of the state of hepatobiliary tract and bones, the catalytical activity of alkaline phosphatase ( EC 3.1.3.1; AP), aspartate aminotransferase (EC 2.6.1.1; AST), alanine aminotransferase (EC 2.6.1.2; ALT) and gammaglutamyltransferase (EC 2.3.2.2; GGT) in serum was monitored as well.

\section{Materials and Methods}

Animals and diets

A total of 42 German Landrace $x$ Piétrain $x$ Large White $x$ Swedish Landrace weaned crossbreds was used in the experiment. Pigs were kept in boxes, seven pigs per box (a total of six boxes). There were seven males and seven females in each group. After weighing, the piglets were divided into three groups: control group, $C(n=14)$, trial group $T_{1}(n=14)$, and trial group $T_{2}(n=14)$. The average starting body mass for all groups of animals was 15.5 $\mathrm{kg}$ (see Table 2). All groups in trial contained pigs from seven different litters born on the same day. Equal number of pigs from one litter (one male and one female) were included in each group. The animals were identified by numbers 1 to 42 , tattooed on the right ear. The male piglets were castrated at the age of $14 \mathrm{~d}$.

All groups of animals were kept in the same microclimatic conditions. During the experimental period the average air temperature was $18.0^{\circ} \mathrm{C}$ and relative humidity $78.8 \%$. There was a forced air circulation in the animal room. The state of health in pigs was checked daily.

Pigs were offered the diets and water ad libitum by means of automatic feeding and watering systems. Composition of fodder mixes is given in Table 1.

Within the $30 \mathrm{~d}$ period preceding the experiment, the piglets became accustomed to the environment and were fed a starter diet (193.10 g. $\mathrm{kg}^{-1}$ of proteins) with no $\mathrm{Zn}$ supplement. By chemical analysis of the starter, $45.5 \mathrm{mg}$ $\mathrm{Zn} . \mathrm{kg}^{-1}$ was determined. This feeding regime was intended to exhaust the $\mathrm{Zn}$ depots in piglets. During the subsequent experimental fattening ( $105 \mathrm{~d}$ ), all groups were fed the same basic fodder mix (Table 1 ) in the following sequence: starter (up to $32 \mathrm{~kg}$ body mass), grower (up to $50 \mathrm{~kg}$ body mass), and finisher (up to $90 \mathrm{~kg}$ body mass).

Control animals were fed the basic fodder mix containing on average $36.7 \mathrm{mg} \mathrm{Zn} . \mathrm{kg}^{-1}$ diet throughout the trial. The $\mathrm{T}_{1}$ group was given an extra $\mathrm{Zn}$ in the form of $\mathrm{ZnSO}_{4}$ : the average addition of $\mathrm{Zn}$ from $\mathrm{ZnSO}_{4}$ was $84.3 \mathrm{mg}$

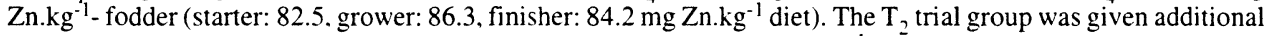
$\mathrm{Zn}$ in $\mathrm{ZnMET}$ : an average addition of $\mathrm{Zn}$ from $\mathrm{ZnMET}$ was $40.9 \mathrm{mg} \mathrm{Zn} \cdot \mathrm{kg}^{-1}$ fodder (starter: 56.3 , grower: 42.3 , finisher: $31.3 \mathrm{mg} \cdot \mathrm{kg}^{-1}$ diet). $\mathrm{ZnSO}_{4}$ and $\mathrm{ZnMET}$ were mixed into vitamin-mineral premixes which were added to the respective starter mix in a concentration of $1 \%$ and to grower and finisher mixes at a concentration of $0.5 \%$.

We measured the following feeding variables: starting and finishing body mass, body mass gain, food intake and feed conversion. They were determined after 4, 8,12 and 15 weeks of experiment. To assess the nutritional effects of zinc supplemented to fodder mixes, blood serum biochemical parameters in experimental and control pigs were compared. Food consumption was measured for a whole group of pigs and the body mass for each animal separately.

As sources of zinc, $\mathrm{ZnSO}_{4} \mathrm{xH}_{2} \mathrm{O}$ (B.B.V. Chemie. Duisburg. Germany) and $\mathrm{Zn}$-methionate (Pliva. Zagreb, Croatia) were used.

Sampling and analyses

All reagents used were of analytical grade. Deionized and then distilled water was used throughout.

During collection and handling of specimens disposable plasticware was used whenever possible. All glassware 
Table 1

Ingredients and chemical composition of diets

\begin{tabular}{|c|c|c|c|}
\hline Ingredients (\% as fed) & Starter & Grower & Finisher \\
\hline \multirow{2}{*}{$\begin{array}{l}\text { Corn } \\
\text { Barley meal }\end{array}$} & 46.05 & 42.50 & 39.50 \\
\hline & 22.00 & 33.45 & 41.00 \\
\hline Wheat middlings & - & - & 3.50 \\
\hline Soybean meal & 19.00 & 13.00 & 9.50 \\
\hline Sunflower meal & - & 6.00 & - \\
\hline Alfalfa meal & 1.50 & 2.50 & 3.40 \\
\hline Fodder Yeast ( vet.) & 6.67 & - & 1.00 \\
\hline Fat & 1.20 & - & - \\
\hline Iodized salt & 0.30 & 0.35 & 0.50 \\
\hline Limestone & 1.15 & 1.00 & 0.80 \\
\hline Dicalcium phosphate & 1.00 & 0.70 & 0.30 \\
\hline$D L$-Methionine & 0.13 & - & - \\
\hline \multicolumn{4}{|l|}{ Vitamin-mineral premix } \\
\hline without antibiotics SP* & 1.00 & - & - \\
\hline \multicolumn{3}{|l|}{ Vitamin-mineral premix } & 0.50 \\
\hline Total & 100.00 & 100.00 & 100.00 \\
\hline \multicolumn{4}{|l|}{ Analysis as fed** } \\
\hline Dry matter $\quad\left(\mathrm{g} \cdot \mathrm{kg}^{-1}\right)$ & 885.60 & 892.00 & 888.00 \\
\hline Crude protein $\left(\mathrm{g} \cdot \mathrm{kg}^{-1}\right)$ & 193.10 & 156.80 & 133.00 \\
\hline Crude fat $\quad\left(\mathrm{g} . \mathrm{kg}^{-1}\right)$ & 37.50 & 30.00 & 26.00 \\
\hline Crude fibre $\quad\left(\mathrm{g} \cdot \mathrm{kg}^{-1}\right)$ & 37.70 & 48.10 & 40.20 \\
\hline $\mathrm{Ca} \quad\left(\mathrm{g} \cdot \mathrm{kg}^{-1}\right)$ & 7.80 & 7.2 & 6.00 \\
\hline$\left(\mathrm{g} \cdot \mathrm{kg}^{-1}\right)$ & 6.50 & 5.30 & 3.80 \\
\hline$\left(\mathrm{mg} \cdot \mathrm{kg}^{-1}\right)$ & 46.00 & 48.70 & 52.37 \\
\hline$\left(\mathrm{mg} \cdot \mathrm{kg}^{-1}\right)$ & 315.00 & 178.26 & 139.40 \\
\hline$\left(\mathrm{mg} \cdot \mathrm{kg}^{-1}\right)$ & 32.50 & 20.24 & 12.30 \\
\hline$\left(\mathrm{mg} \cdot \mathrm{kg}^{-1}\right) \mathrm{C}$ & 45.50 & 38.00 & 31.00 \\
\hline$\left(\mathrm{mg} \cdot \mathrm{kg}^{-1}\right)+\mathrm{T}_{1}$ & 128.00 & 124.26 & 115.20 \\
\hline$\left(\mathrm{mg} \cdot \mathrm{kg}^{-1}\right) \# \mathrm{~T}_{2}$ & 101.80 & 80.30 & 62.33 \\
\hline
\end{tabular}

* Vitamin-mineral premixes contained:

$\mathrm{Zn}$ - free VAM - SP provided the following per kilogram: vitamin A, 1,000.000 IU; vitamin $\mathrm{D}_{3}, 100,000 \mathrm{ICU}$; vitamin E, 1,500 $\mathrm{mg}$; vitamin $\mathrm{K}_{3}, 200 \mathrm{mg}$; vitamin $\mathrm{B}_{1}, 200 \mathrm{mg}$; vitamin $\mathrm{B}_{2}, 400 \mathrm{mg}$; niacin 2,500 mg; $D$-pantothenic acid, 1,500 mg; vitamin $\mathrm{B}_{6}$, $300 \mathrm{mg}$; vitamin $\mathrm{B}_{12}, 2 \mathrm{mg}$; biotin, $10 \mathrm{mg}$; choline chloride, $50,000 \mathrm{mg} ; \mathrm{Fe}, 10.000 \mathrm{mg}$; Cu, 2,000 mg; Mn, 3,000 mg; J, 75 mg; $\mathrm{Co}, 30 \mathrm{mg}$; Se, $10 \mathrm{mg}$. Additions of $\mathrm{Zn}$ were $8,000 \mathrm{mg}$ from $\mathrm{ZnSO}_{4}$ and $4,000 \mathrm{mg}$ from $\mathrm{ZnMET}$.

$\mathrm{Zn}$-free VAM - ST provided the following per kilogram; vitamin A, 1,000.000 IU; vitamin D3, 100,000 ICU; vitamin E, $2,400 \mathrm{mg}$; vitamin $\mathrm{K}_{3}, 400 \mathrm{mg}$; vitamin $\mathrm{B} 1,400 \mathrm{mg}$; vitamin $\mathrm{B}_{2}, 600 \mathrm{mg}$; niacin, 3,000 mg; $D$-pantothenic acid 2,000 mg; vitamin $\mathrm{B}_{6}, 400 \mathrm{mg}$; vitamin $\mathrm{B}_{12}, 3 \mathrm{mg}$; choline chloride, $100,000 \mathrm{mg}$; Fe, 16,000 mg: Cu, 4,000 mg: Mn, 8,000 mg; J, $150 \mathrm{mg}: \mathrm{Co}, 40$ $\mathrm{mg}$; Se, $20 \mathrm{mg}$. Additions of $\mathrm{Zn}$ were $16,000 \mathrm{mg}$ from $\mathrm{ZnSO}_{4}$ and $8,000 \mathrm{mg}$ from $\mathrm{Zn}$.MET.

** Official methods were used throughout ( A.O.A.C., 1984).

$\dagger$ After addition of $\mathrm{ZnSO}_{4}$ to a vitamin-mineral premix.

\# Afer addition of ZnMET to vitamin-mineral premix.

was acid-washed (soaked in $1: 1 \mathrm{HNO}_{3}$ for $24 \mathrm{hr}$ and rinsed thoroughly with water). Blood was taken using special purpose trace element (low $\mathrm{Zn}$ ) evacuated tubes with stainless steel needles. Blood samples were allowed to clot in Falcon polystyrene labware tubes (Falcon, Oxnard, CA, USA) and the serum was stored in the same type of tubes.

These tubes were used also for preparing sample dilution's.

Blood samples were taken from the brachial region (v. cava cranialis) at the same time of the day ( 08.00 to 11.00 $\mathrm{h}$ ) from the same animals and in the same group sequence. Blood was sampled from each individual in the group after a $12 \mathrm{~h}$ fasting.

Analysis of $\mathrm{Zn}$ concentration in blood serum was performed by flame atomic- absorption spectrometry (PerkinElmer 305B atomic absorption spectrophotometer, Perkin-Elmer, Norfolk. CAT, USA) under standard operating conditions. Samples were prepared by diluting sera with water in a volume ratio 1:4. The diluent used for the preparation of a blank and of standard solutions was $5 \%(\mathrm{~V} / \mathrm{V})$ glycerol (Perk in-El mer 1976; B u tri m o vit z and Purdy 1977; S mith et al. 1979). The accuracy of the method was checked upon lyophilised control serum Validate-A (Lot No. 101553, Organon Teknika, Eppelheim, Germany). 
Determination of $\mathrm{Zn}$ in both bone and hair was done by graphite furnace atomic-absorption spectrometry (Unicam 920 AA spectrometer with Unicam GF 90 furnace, Unicam, Cambridge, UK). The samples were collected and treated as follows: At the end of the experiment, pigs from all groups were killed and the coccygeal vertebrae were collected for $\mathrm{Zn}$ analysis. The feet and tails were autoclaved at $120^{\circ} \mathrm{C}$ for $20 \mathrm{~min}$ to facilitate the removal of muscle, skin and connective tissue. The bones were then dried at $105^{\circ} \mathrm{C}$ overnight. The dried bones were then extracted with anhydrous ethyl ether for $48 \mathrm{hr}$. The dried, fat-free bones were than ashed at $720^{\circ} \mathrm{C}$ for $3 \mathrm{hr}$. Bone samples were dissolved in $6 \mathrm{moll}^{-1} \mathrm{HCl}$ and diluted appropriately for the $\mathrm{Zn}$ analysis. At the beginning of the experiment an average sample of hair was taken from all groups, and at the end of the experiment, the animals in each group were sampled. The same ashing procedure followed by dissolution in $\mathrm{HCl}$ as stated for bones was applied to hair samples as well.

Catalytical activities of AP. AST, ALT and GGT in blood serum were determined using Chronolab test reagents at $30^{\circ} \mathrm{C}$. Spectrometric measurements were performed on an automatic analyser (VP - ABBOT).

Animals employed in this study were maintained in facilities approved by the Croatian Association for Accreditation of Laboratory Animals Care and in accordance with current regulations and standards of the Croatian Ministry of Agriculture.

Statistics

All statistical analyses were performed using the GLM procedure of SAS (1989).

\section{Results}

\section{Feeding variables}

Mean values of feeding variables investigated over $105 \mathrm{~d}$ of experimental fattening are given in Table 2. No significant difference was detected in the body mass among the three groups at the beginning of the trial. During the trial pigs in groups $T_{1}$ and $T_{2}$ attained greater

Table 2

\section{Average feeding variables after $105 \mathrm{~d}$ of the trial}

\begin{tabular}{|lccc|}
\hline & \multicolumn{3}{c|}{ Group of animals* } \\
\cline { 2 - 4 } Feeding variable & $\mathrm{C}$ & $\mathrm{T}_{1}$ & $\mathrm{~T}_{2}$ \\
\hline Body mass $(\mathrm{x} \pm \sigma, \mathrm{kg})$ & & & \\
Starting & $15.65 \pm 1.82$ & $15.41 \pm 2.77$ & $15.42 \pm 2.31$ \\
Finishing & $82.25 \pm 12.82$ & $94.50 \pm 8.87$ & $95.97 \pm 8.83$ \\
Index (\%) & 100 & 114.9 & 116.7 \\
Daily mass gain $(\mathrm{x} \pm \sigma, \mathrm{g})$ & $634.43 \pm 120.15^{* *}$ & $753.24 \pm 97.57^{* *}$ & $767.14 \pm 83.90^{* *}$ \\
Index (\%) & 100 & 118.8 & 120.9 \\
Daily food intake $(\mathrm{x}, \mathrm{kg})$ & 2.08 & 2.38 & 2.45 \\
Index $(\%)$ & 100 & 114.4 & 117.8 \\
Feed conversion $\left(\mathrm{x}, \mathrm{kg} \cdot \mathrm{kg}^{-1}\right)$ & 3.28 & 3.16 & 3.19 \\
Index $(\%)$ & 100 & 96.3 & 97.3 \\
\hline
\end{tabular}

* Number of pigs in each group, $\mathrm{n}=14$.

** Significant difference $(\mathrm{P}<0.05)$ of average feeding variables between trial groups and the control group.

( $\mathrm{P}<0.05$ ) body mass (by 14.9-16.7\%) and body mass gain (by 18.8-20.9\%) than the controls. Comparison of $\mathrm{C}$ group with $\mathrm{T}_{1}$ and $\mathrm{T}_{2}$ trial pointed also to the higher daily food intake (14.4$17.8 \%$ ) of the latter. Better feed conversion (by $2.7-3.7 \%$ ) was also recorded in $\mathrm{T}_{1}$ and $\mathrm{T}_{2}$ than in $\mathrm{C}$ group. Fair but not significant improvements of feeding variables were evidenced in group $T_{2}$ if compared with group $T_{1}$.

Table 3 gives the data on $\mathrm{Zn}$ concentration in blood serum, bone and hair (mean $\pm \sigma$ ) as well as the percentage of animals suffering from parakeratosis. 
Table 3

Effect of dietary zinc on serum, bone and hair zinc content and percent of parakeratotic swine

\begin{tabular}{|c|c|c|c|}
\hline \multirow{2}{*}{ Day } & \multicolumn{3}{|c|}{ Group of animals* } \\
\hline & $\begin{array}{c}C \\
(x \pm \sigma)\end{array}$ & $\begin{array}{c}T_{1} \\
(x \pm \sigma)\end{array}$ & $\begin{array}{c}\mathrm{T}_{2} \\
(\mathrm{x} \pm \sigma)\end{array}$ \\
\hline \multicolumn{4}{|l|}{1 (initial) } \\
\hline Serum $\mathrm{Zn}\left(\mu \mathrm{g} \cdot \mathrm{ml}^{-1}\right)$ & $0.73 \pm 0.14$ & $0.71 \pm 0.14$ & $0.73 \pm 0.15$ \\
\hline Hair Zn $\left(\mu \mathrm{g} \cdot \mathrm{g}^{-1}\right)^{* *}$ & & $102.10 \pm 0.15$ & \\
\hline Parakeratosis (\%) & 0 & 0 & 0 \\
\hline \multicolumn{4}{|l|}{28} \\
\hline Serum Zn $\left(\mu \mathrm{g} \cdot \mathrm{ml}^{-1}\right)$ & $1.09 \pm 0.17 \dagger$ & $1.56 \pm 0.51 \dagger$ & $2.48 \pm 1.54 \dagger$ \\
\hline Parakeratosis $(\%)$ & 100 & 0 & 0 \\
\hline \multicolumn{4}{|l|}{56} \\
\hline Serum $\mathrm{Zn}\left(\mu \mathrm{g} \cdot \mathrm{ml}^{-1}\right)$ & $0.28 \pm 0.07 \dagger$ & $1.28 \pm 0.14 \dagger$ & $1.17 \pm 0.14 \dagger$ \\
\hline Parakeratosis (\%) & 100 & 0 & 0 \\
\hline \multicolumn{4}{|l|}{105} \\
\hline Serum $\mathrm{Zn}\left(\mu \mathrm{g} \cdot \mathrm{ml}^{-1}\right)$ & $0.39 \pm 0.14 \dagger$ & $1.34 \pm 0.27 \dagger$ & $1.26 \pm 0.37 \dagger$ \\
\hline Bone $\mathrm{Zn}\left(\mu \mathrm{g} \cdot \mathrm{g}^{-1}\right)^{* * *}$ & $83.81 \pm 16.88 \dagger$ & $111.80 \pm 17.20 \dagger$ & $103.60 \pm 18.67 \doteqdot$ \\
\hline Hair $\mathrm{Zn}\left(\mu \mathrm{g} \cdot \mathrm{g}^{-1}\right)^{* * *}$ & $153.94 \pm 5.74 \dagger$ & $186.55 \pm 14.78 \dagger \#$ & $173.62 \pm 10.13 \div \#$ \\
\hline Parakeratosis $(\%)$ & 0 & 0 & 0 \\
\hline
\end{tabular}

* Number of parallels, $n=14$ for serum, $n=6$ for bone and hair.

** $\mathrm{Zn}$ content in hair expressed per gram of dry hair.

*** $\mathrm{Zn}$ content in bone expressed per gram of dry, fat-free bone.

$\dagger \quad$ Significant difference $(\mathrm{P}<0.05)$ of average $\mathrm{Zn}$ levels between either of trial groups and control group.

\# $\quad$ Significant difference $(P<0.05)$ of average $Z n$ levels between trial groups.

At the beginning of the trial ( $\mathrm{d}$ 1) no significant difference of $\mathrm{Zn}$ concentration in serum between groups of animals was found. After $28 \mathrm{~d}$ of experimental fattening, a considerable increase of $\mathrm{Zn}$ concentration in serum was observed in all groups of animals, followed by a remarkable drop and another increase.

After 28, 56 and $105 \mathrm{~d}$ of the experimental feeding regime, in control animals a lower ( $P<0.05$ ) concentration of $\mathrm{Zn}$ in serum was found as compared to $T_{1}$ and $T_{2}$ pigs. No significant difference in serum $Z n$ concentration between $T_{1}$ and $T_{2}$ was observed. However, after the first month of $\mathrm{Zn}$ supplementation a high variability in response of animals to ZnMET was observed. It might have contributed to a transient hyperzincaemia recorded in group $\mathrm{T}_{2}$.

At the beginning of the experiment, there were no signs of parakeratosis found in any of the groups. After 28 days, however, there was clinical evidence of typical parakeratosis in all control animals. They suffered from reduced appetite and changes on the whole skin (on belly in particular) with intensive itching and red round swellings covered with crusts $(1-2 \mathrm{~cm}$ in diameter) that tended to become confluent. During subsequent four weeks of the trial (until d 56), the parakeratotic changes persisted (Plate II. Fig. 1 and 2).

In the period from d 56 to $d 105$ of the trial, the parakeratotic signs on the skin of control pigs disappeared. On the other hand, none of the trial animals have shown signs of parakeratosis throughout the experiment.

The accumulation of $\mathrm{Zn}$ in bones of pigs was observed at the end of experiment: the $\mathrm{Zn}$ concentration in $\mathrm{T}_{1}$ and $\mathrm{T}_{2}$ was higher $(\mathrm{P}<0.05)$ than that in $\mathrm{C}$ group. 
During the trial, an average increase in $\mathrm{Zn}$ concentration in swine hair of approximately $70 \%$ was recorded. Upon experimental fattening the $\mathrm{Zn}$ concentration was higher $(\mathrm{P}<0.05)$ in $\mathrm{T}_{1}$ and $\mathrm{T}_{2}$ than in controls. Moreover, a higher $(\mathrm{P}<0.05)$ value was found in the $\mathrm{T}_{1}$ than in $\mathrm{T}_{2}$ group.

Enzyme catalytical activities

Catalytical activity of enzymes AP, AST, ALT and GGT in serum of pigs (mean $\pm \sigma$ ) as monitored throughout the trial is presented in Table 4.

Table 4

Catalytical activity $\left(\mu \mathrm{kat}^{-\mathrm{I}^{-1}}\right)$ of AP, AST, ALT and GGT in serum

\begin{tabular}{|c|c|c|c|c|}
\hline \multirow[b]{2}{*}{ Enzyme } & \multirow[b]{2}{*}{ Day } & \multicolumn{3}{|c|}{ Group of animals* } \\
\hline & & $\begin{array}{c}C \\
(x \pm \sigma)\end{array}$ & $\begin{array}{c}T_{1} \\
(x \pm \sigma)\end{array}$ & $\begin{array}{c}\mathrm{T}_{2} \\
(\mathrm{x} \pm \sigma)\end{array}$ \\
\hline AP & $\begin{array}{c}1 \\
28 \\
56 \\
105\end{array}$ & $\begin{array}{l}2.97 \pm 0.49 \\
1.95 \pm 0.44 \mathrm{II} \\
0.96 \pm 0.34 \mathrm{II} \\
0.65 \pm 0.30 \mathrm{I}\end{array}$ & $\begin{array}{l}2.35 \pm 0.71 \\
2.80 \pm 0.63 \mathrm{II} \\
3.00 \pm 0.56 \mathbb{I} \\
1.54 \pm 0.71 \mathrm{I}\end{array}$ & $\begin{array}{l}2.73 \pm 0.86 \\
2.68 \pm 0.509 \\
2.99 \pm 0.809 \\
1.51 \pm 0.329\end{array}$ \\
\hline AST & $\begin{array}{c}1 \\
28 \\
56 \\
105\end{array}$ & $\begin{array}{l}0.80 \pm 0.34 \\
0.77 \pm 0.22 \mathbb{I} \\
0.71 \pm 0.19 \mathbb{I} \\
0.65 \pm 0.25\end{array}$ & $\begin{array}{l}0.85 \pm 0.33 \\
0.61 \pm 0.119 \\
0.53 \pm 0.12 \mathrm{~g} \\
0.82 \pm 0.55\end{array}$ & $\begin{array}{l}0.79 \pm 0.15 \\
0.70 \pm 0.18 \\
0.48 \pm 0.079 \\
0.66 \pm 0.25\end{array}$ \\
\hline ALT & $\begin{array}{c}1 \\
28 \\
56 \\
105\end{array}$ & $\begin{array}{l}0.78 \pm 0.17 \\
0.66 \pm 0.16 \\
0.37 \pm 0129 \\
0.70 \pm 0.12\end{array}$ & $\begin{array}{l}0.77 \pm 0.23 \\
0.74 \pm 0.13 \\
0.40 \pm 0.13 \# \\
0.74 \pm 0.12\end{array}$ & $\begin{array}{l}0.66 \pm 0.15 \\
0.68 \pm 0.08 \\
0.55 \pm 0.08 \mathrm{I} \# \\
0.69 \pm 0.13\end{array}$ \\
\hline GGT & $\begin{array}{c}1 \\
28 \\
56 \\
105\end{array}$ & $\begin{array}{l}0.64 \pm 0.17 \\
0.51 \pm 0.16 \\
0.94 \pm 0.41 \mathbb{1} \\
0.87 \pm 0.51 \Phi\end{array}$ & $\begin{array}{l}0.65 \pm 0.21 \\
0.51 \pm 0.30 \\
0.79 \pm 0.23 \# \\
0.70 \pm 0.18\end{array}$ & $\begin{array}{l}0.64 \pm 0.29 \\
0.46 \pm 0.16 \\
0.57 \pm 0.309 \# \\
0.59 \pm 0.249\end{array}$ \\
\hline
\end{tabular}

* Number of parallels, $\mathrm{n}=14$.

II Significant difference $(\mathrm{P}<0.05)$ of average catalytical activity between either of trial groups and the control group. \# Significant difference $(\mathrm{P}<0.05)$ of average catalytical activity between trial group.

At the beginning of the trial there was no statistically significant difference in catalytic activity of any of the enzymes studied among any of the groups.

During the experimental fattening, however, a continuous downward trend of the AP catalytical activity was observed in $\mathrm{C}$ group. The respective values were always lower than those in $T_{1}$ and $T_{2}$. Meanwhile, until $d 56$ in groups $T_{1}$ and $T_{2}$ almost the same and constant values were attained. A remarkable decline in catalytical activity was only recorded at the end of experiment.

Considering the AST catalytical activity, no significant differences among $\mathrm{C}$ and $\mathrm{T}_{1}$ and $\mathrm{T}_{2}$ groups were found either at the beginning or at the end of the experiment. However, during the second month of experimental feeding regime such differences were observed. Cgroup showed a slow but persistent declining trend of the AST activity, but with still higher $(P<0.05)$ values in comparison with trial groups until $d 56$. In both trial groups similar by restoration to initial values. 
Significant difference $(\mathrm{P}<0.05)$ of catalytical activity of ALT between control and either of trial groups was only found on $\mathrm{d} 56$. At this point activity recorded in group $\mathrm{T}_{2}$ was significantly higher than that in $\mathrm{C}$ and $\mathrm{T}_{1}$ groups. In all experimental groups a similar minimum activity on $\mathrm{d} 56$ was found.

There were no differences detected in GGT catalytical activity of $C, T_{1}$ and $T_{2}$ groups during the trial, with nearly the same dynamics reaching their minimum on $\mathrm{d} 28$. Lower $(\mathrm{P}<0.05)$ activity in $\mathrm{T}_{2}$ pigs compared to controls was found at the end of the second month of the experiment.

\section{Discussion}

During the $30 \mathrm{~d}$ period preceding the experiment, all piglets were fed a starter $(45.5 \mathrm{mg}$ $\mathrm{Zn} \cdot \mathrm{kg}^{-1}$ fodder mix) with no extra $\mathrm{Zn}$ supplement. This resulted in serum $\mathrm{Zn}$ being at the lower limit of the physiological range $\left(0.70-1.50 \mathrm{~g} \cdot \mathrm{ml}^{-1}\right),(\mathrm{Pu} \mathrm{l} \mathrm{s}$ 1990) though higher than the values reported for $\mathrm{Zn}$ deficiency $\left(0.40-0.50 \mathrm{~g} \cdot \mathrm{ml}^{-1}\right)$, (Hoekstra et al. 1967). Nevertheless, this relatively low zinc concentration was not accompanied by reduced diet intake or other clinical manifestations of $\mathrm{Zn}$ deficiency. This feeding regime was aimed at exhaustion of the $\mathrm{Zn}$ depots (liver, bones and other tissues) in all groups of pigs in order to detect nutritional efficiency, if any, of different amounts and sources of dietary $\mathrm{Zn}$ in trial groups.

It should be noted that during the second month of the experiment clinical signs of typical parakeratosis (itching, discoloured skin) were evident in all control animals but in none of trial animals. During the whole trial ( $105 \mathrm{~d}$ ) performance data in all animals were very good. Clinical signs of parakeratosis were accompanied by deteriorated production data in the controls e.g. by reduced food consumption and lower body mass gain compared to $T_{1}$ and $T_{2}$ pigs. In the period from d 56 to $\mathrm{d} 105$ parakeratotic changes on the skin of control animals disappeared but itching and poor production continued. Disappearance of pathological parakeratotic changes may be attributed first to a decline of growth rate and body mass gain (diminished protein synthesis rate) in this period when feed began to be predominantly converted into fats, and secondly by increased food intake sufficient to cover the basic metabolic needs for zinc.

The finding of transient increase of $\mathrm{Zn}$ concentration in blood serum of control pigs was somewhat surprising at a time when parakeratotic changes first occurred. They were culminating at the time when the lowest serum $\mathrm{Zn}$ concentration was measured on $\mathrm{d} 56$ $\left(0.28 \mu \mathrm{g} \cdot \mathrm{ml}^{-1}\right)$. This coincided with the substitution of starter with grower (containing lower $\mathrm{Zn}$ amount) and reduced food intake.

Our results are in accordance with those of E d e r et al. (1996) who reported on decreased serum $\mathrm{Zn}$ concentration by $70 \%$ as a consequence of dietary $\mathrm{Zn}$ deficiency. Groups $\mathrm{T}_{1}$ and $\mathrm{T}_{2}$ showed significantly higher $\mathrm{Zn}$ concentrations in serum than control group; moreover, neither symptoms of parakeratosis nor any other health disturbance was noticed. This is in accordance with the fact that the serum $\mathrm{Zn}$ stabilized at the upper physiological limit. Considerable drop of $\mathrm{Zn}$ concentration in serum during the second month of the trial $(\mathrm{d} 28$ 56) may be explained by both intensive body mass gain and augmented synthesis of metallothionein. Compared to the first month of the experiment, daily body mass gain recorded during the second month for groups $T_{1}$ and $T_{2}$ was increased on average by 16 and $11 \%$, respectively. This resulted in increased metabolic need for zinc. On the other hand, the abundant intake of zinc in both groups probably induced the synthesis of metallothionein (Kelly et al. 1996; Richards 1989) that bound the excess of zinc and stored it in the liver, bones, and pancreas. In addition, successive decrease of $\mathrm{Zn}$ concentration (added as ZnMET) in starter, grower and finisher diets may have participated in the decreasing serum zinc concentration in $\mathrm{T}_{2}$ group. 
$\mathrm{Zn}$ concentrations in serum speak in favour of higher nutritional availability and efficiency of organic zinc during the whole trial, particularly in first 2-3 months of life when growth and body mass gain (predominantly protein synthesis) is very intensive. Although the concentration of $\mathrm{Zn}$ supplemented to trial animals in the form of metalo-organic chelate was half the amount of the inorganic salt it was enough to cover the metabolic requirements and maintain good health and performance of animals. All these facts confirm the better bioavailability of $\mathrm{Zn}$ from $\mathrm{ZnMET}$ than from $\mathrm{ZnSO}_{4}$. This is in accordance with the results of Hill et al. (1986), Swinkels et al. (1991) and Wedekind et al. (1992. 1994). Better bioavailability of $\mathrm{Zn}$ from chelate presumably results also in markedly lower amount of $\mathrm{Zn}$ eliminated by faeces and in reduced contamination of environment. Therefore, as a diet additive. $\mathrm{ZnMET}$ is preferred over $\mathrm{ZnSO}_{4}$ from both nutritional and ecological point of view.

Our results on $\mathrm{Zn}$ amount found in coccygeal vertebrae as well as the deposition sequence of $\mathrm{Zn}$ from different sources in bones are in agreement with findings of $\mathrm{W}$ e de $\mathrm{k}$ ind et al. (1994). Our values, however, are lower than those of Hoekstra et al. (1967) reported for adult pigs.

Remarkable nutritional influence of different sources of zinc on porcine hair was demonstrated first by a sharp increase in $\mathrm{Zn}$ content in hair which was on average $70 \%$, and also by higher concentration of zinc in $T_{1}$ and $T_{2}$ groups than in control group. However, significantly greater amount of inorganic than of organic zinc was deposited in hair. At the end of experiment we found $\mathrm{Zn}$ concentrations in hair exceeding considerably those reporterd for adult pigs by Hoekstra et al. (1967).

Feed efficiency of $\mathrm{Zn}$ supplemented to fodder mixes was also documented through superior feeding variables found in $\mathrm{T}_{1}$ and $\mathrm{T}_{2}$ groups compared to control. However, better feeding variables observed in $T_{2}$ compared to $T_{1}$ were not significant. All nutritional indicators evaluated in our experiment are in full accordance with the similar results obtained by Wedekind et al. (1994).

Catalytical activity of AP in serum is a valuable diagnostic tool. Apart from other clinical and biochemical evidence, the increased activity of AP indicates pathological processes in bones, liver and bile ducts, whereas its lower activity points to disturbances in synthesis of AP which may result in decreased deposition of minerals in skeleton. Since $\mathrm{Zn}$ is a part of AP molecule, it is essential both for its synthesis and catalytical activity. Animals fed inadequate $\mathrm{Zn}$ amount may obtain insufficient $\mathrm{Zn}$ amount to cover their basic metabolic needs with resulting low AP activity in serum. This was apparently the case in our control animals having significantly lower catalytical activity of $A P$ than $T_{1}$ and $T_{2}$ and decreasing throughout the experiment (see Table 4). On the other hand, in $T_{1}$ and $T_{2}$ pigs, high and practically constant values were recorded. Irrespectively of the organic or inorganic zinc supplied almost the same $\mathrm{Zn}$ concentrations were found in trial groups. These results support the idea of a direct correlation between AP catalytical activity in serum and diet $\mathrm{Zn}$ intake. Moreover, a linear correlation (correlation coefficient of 0.90) was found between AP catalytical activity and $\mathrm{Zn}$ concentration in serum. Our results are consistent with data of Luecke et al. (1958) and Hoefer et al. (1958, 1960) who investigated the influence of $\mathrm{Zn}$-deficient feeding regime accompanied by metabolic disorder of parakeratosis on the concentration of $\mathrm{Zn}$ and catalytical activity of AP. However, our experimental data for the AP activity in serum of both trial groups were beyond those reported by $\mathrm{Imlah}$ and M c Taggart (1977) and Foren bacher (1993) for healthy pigs. Just the opposite is true for the controls (O dink et al. 1990).

Lower catalytical activity of AP in serum of control pigs pointed to subclinical disturbances in bones confirmed by lower $(\mathrm{P}<0.05)$ concentration of $\mathrm{Zn}$ than in the groups 
$T_{1}$ and $T_{2}$. $Z n$ deficiency in controls was also reflected in lower $(P<0.05)$ level of $\mathrm{Zn}$ in hair compared to trial pigs.

Aminotransferases (AST, ALT) and GGT take part in metabolism of proteins, and they indicate pathological processes in liver and, to a lesser extent, serve to evaluate the muscular activity (AST).

Throughout the trial the catalytical activity of AST was high in controls, on d 28 and 56 even surpassing $(\mathrm{P}<0.05)$ that of $\mathrm{T}_{1}$ and $\mathrm{T}_{2}$ pigs. Interestingly, at this time control pigs have shown parakeratotic changes. Their AST activity had a slight continuous downward trend. At the end of experiment, when parakeratotic changes on skin ceased, no difference in AST between $C$ versus $T_{1}$ and $T_{2}$ pigs was found. Hence it seems that in the course of development of pathological changes on the skin during intensive body mass gain (protein synthesis prevailing in skeletal muscles) AST activity raises.

Our data on AST catalytical activity in swine serum were higher than those reported as physiological by Imlah and McTaggart (1977), Žurić and Stanković (1991) and Forenbacher (1993) but remarkably lower than those found by Odink et al. (1990) in healthy pigs.

Catalytical activity of ALT in serum was almost the same in control and in trial groups throughout the experiment, indicating that neither deficiency nor addition of zinc affected the activity of this enzyme. No chronic dietary hepatosis was thus diagnosed. Our data for catalytical activity of ALT are comparable with those of O d in k et al. (1990) but markedly higher than those of Žurić and Stanković (1991) and Forenbacher (1993).

No differences were found in the catalytical activity of GGT on $\mathrm{d} 1$ and 28 among C, $\mathrm{T}_{1}$ and $T_{2}$ pigs. However, on $\mathrm{d} 56$ and 105 detected higher GGT activity in $\mathrm{C}$ pigs was indicative of a possible liver malfunction in these animals caused by a long-term deficiency of zinc in the diet. Moreover, a linear correlation of GGT catalytical activity and serum Zn level with a correlation coefficient of -0.72 was established. Our values for the GGT activity in control animals until d 28 and in trial animals throughout the experiment were comparable with those found by Žurić and Stanković (1991) and Forenbacher (1993) for healthy pigs, but somewhat higher in regard to the controls in the period from d 28 to the end of experiment. However, our values were remarkably lower than those of Odink et al. (1990).

Some differences in our data for catalytical activities of AP, AST, ALT and GGT compared to those reported in literature might be attributed to different experimental conditions, possibly incubation temperature. Because our values were measured at $30{ }^{\circ} \mathrm{C}$ they were expectedly higher than those reported by $\mathrm{Imlah}$ and Mc Taggart (1977), Žurić and Stanković (1991) and Forenbacher (1993) for $24^{\circ} \mathrm{C}$, comparable to those measured by Lue cke et al. (1958) and Hoefer et al. $(1958 ; 1960)$ at $30^{\circ} \mathrm{C}$, and lower than those of $\mathrm{O}$ din $\mathrm{k}$ et al. (1990) obtained at $37^{\circ} \mathrm{C}$.

\section{Vliv příjmu anorganického a organického zinku na jeho koncentraci v krevním séru, v kostech, ve štětinách a vliv na katalytickou aktivitu některých sérových enzymů u prasat}

V práci je srovnáván vliv př́ijmu zinku z anorganického a organického zdroje u prasat trpících jeho deficitem. Třicet dnủ před pokusem byl zjištěn u vyšetřovaných prasat (německá landrase $\times$ pietrain $\times$ bílé ušlechtilé $\times$ švédská landrase) nedostatek zinku. Prasata byla rozdělena do tří skupin po 14 kusech. Během experimentálního krmného období ( 105 dnů) nebyla kontrolní skupina krmena vyšším obsahem zinku, zatímco zbývajícím dvěma pokusným skupinám byl podáván zinek ve formě anorganické $\left(\mathrm{ZnSO}_{4}\right)$ a ve formě metaloorganického 
chelátu (methionát zinku). Jednotlivé vzorky obsahovaly průměrně $84,3 \mathrm{mg}$ $\mathrm{Zn} / \mathrm{kg}^{-1}$ a $40,9 \mathrm{mg} \mathrm{Zn} / \mathrm{kg}^{-1}$ v krmivu.

Hodnocení výživného účinku zinku bylo založeno na jeho koncentraci v krevním séru, v kostech a ve štětinách. Dále byl studován vliv zinku na katalytickou aktivitu alkalické fosfatázy, aspartát aminotransferázy, alanin aminotransferázy a gama-glutamyl transferázy v séru.

Snížená katalytická aktivita aspartát aminotransferázy a alanin aminotransferázy byla zaznamenána současně s parakeratózou kůže u kontrolních zviŕăat a nevztahovala se k množství zinku $\mathrm{v}$ séru. $\mathrm{V}$ protikladu $\mathrm{k}$ těmto nálezům byla zaznamenána lineární korelace mezi katalytickou aktivitou alkalické fosfatázy a gama-glutamyl transferázy a koncentrace zinku v séru se pohybovala od 0,90 do $-0,72$.

Výživná hodnota zkrmovaného zinku byla vyšší $(P<0,05)$ v séru, v kostech, ve štětinách, $\mathrm{v}$ hepatobiliárním traktu a ve srovnání $\mathrm{s}$ kontrolní skupinou byly získány příznivé výsledky.

U žádného pokusného zviŕete nebyly zjištěny jiné zdravotní problémy. U kontrolních zvířat propukla progresívní parakeratóza, která pokračovala ještě do druhého měsíce pokusu. Tím byly nepříznivě ovlivněny získané údaje postižených zvířat.

Pokusem jsme dokázali, že zinek byl lépe využit z chelátu než z anorganických solí, zejména $v$ období rychlého růstu. Vzhledem $\mathrm{k}$ lepšímu využití u prasat a $\mathrm{z}$ hlediska ekologického by měla být dána přednost krmivu obohacenému $\mathrm{ZNSO}_{4}$.

\section{Acknowledgement}

Our thanks are due to I. Cepelak for her helpful discussions.

\section{References}

A.O.A.C. 1984: Official Methods of Analysis (14th Ed.). Association of Official Analytical Chemists, Arlington, VA, USA

BERRIE, R. A., HALFORD, D. M., GALYEAN, M. L., BIRCH, M. W., CHRISTENSEN, B. L., SCHNEIDER, F. A., ORTIZ, A. 1994: Growth and carcass characteristics of lambs fed supplemental zinc sulfate or zinc methionine. Proceeding, Western Section, American Society of Animal Science 45:137-139

BUTRIMOVITZ, G. P., PURDY, W. C. 1977: The determination of zinc in blood plasma by atomic absorption spectrometry. Anal. Chim. Acta 94:63-73

EDER, K., HARTMANN, S., KIRCHGESSNER, M. 1996: The effect of zinc deficiency on fatty acid composition of various tissues in the growing pig. Nutr. abstr. and rev. B. 66: 204 (Abstract 1384)

FORENBACHER, S. 1993: Clinical pathology of digestion and metabolism of domestic animals Vol. II: Liver. (In Croatian). HAZU i Školska knjiga, Zagreb. pp. 552

HARTFIELD, P. G., SNOWDER, G. D., HEAD, W. A. Jr., GLIMP, H. A., STOBART, R. H., BESSER, T. 1995: Production by ewes rearing single or twin lambs: Effects of dietary crude protein percentage and supplemental zinc methionine. J. Anim. Sci. 73:1227-1238

HERRICK, J. 1989: Zinc methionine: Feedlot and dairy indications, Large Anim. Vet. 67: 835

HILL, D. A., PEO, E. R. Jr., LEWIS, A. J., CRENSHAW, J. D. 1986: Zinc- amino acid complexes for swine. J. Anim. Sci. 63:121-130

HOEFER, J. A., ULLREY, D. E., MILLER, E. R., LUECKE, R. W. RITCHIE, H. D. 1958: The effect of feeding zinc, iron and copper to pigs from weaning to market weight. J. Anim. Sci. 17:1186 (Abstract)

HOEFER, J. A., MILLER, E. R., ULLREY, D. E., RITCHE, H. D., LUECKE, R. W. 1960: Interrelationships between calcium, zinc, iron and copper in swine feeding. J. Anim. Sci. 19:249-259

HOEKSTRA, W. G., FALTIN, E. C., LIN, C. W., ROBERTS, H. F., GRUMMER, R. H. 1967: Zinc deficiency in reproducting gilts fed a diet high in calcium and its effect on tissue zinc and blood serum alkaline phosphatase. J. Anim. Sci. 26:1348-1357

IMLAH, P., McTaggart, H. S. 1977: Haematology of the pig. In: Comparative clinical Haematology. Archer, R. K. \& L. B. Jeffcott ed. Blackwell Scientific Publications. pp. 286

KELLY, E. J., QUAIFE, C. J., FROELICK, G. J., PALMITER, R. D. 1996: Metallothionein I and II Protect against Zinc Deficiency and ZincToxicity in Mice. J. Nutr. 126:1782-1790

LUECKE. R. W., HOEFER, J. A., BRAMMELLM, W. S., SCHMIDT, D. A. 1957: Calcium and zinc in parakeratosis of swine. J. Anim. Sci. 16:3-11 
LUECKE, R. W., SCHMIDT, D. A., HOEFER, J. A. 1958: Serum alkaline phosphatase as affected by dietary calcium and zinc levels in swine. J. Anim. Sci. 17:1185 (Abstract)

MILNE, D. B. 1994: Trace elements. In: Tietz Textbook of Clinical Chemistry. Burtis, C. A. \& E. R. Ashwood ed. W. B Saunders Company, Philadelphia, pp. 1317-1349

ODINK, J., SMEETS, J. F. M.. VISSER, I. J. R., SANDMAN, H., SNIJDERS, J. M. A. 1990: Hematological and clinicochemical profiles of healthy swine and swine with inflammatory processes. J. Anim. Sci. 68:163-170

PERKIN-ELMER. 1976: Analytical Methods for Atomic Absorption Spectrophotometry. Perkin-Elmer, Norwalk, CT, USA, pp. BC-5

PULS, R. 1990: Mineral levels in Animal Health: Diagnostic Data. Clearbook, Sherpa International, British Columbia, Canada.

RICHARDS, M. P. 1989: Recent Developments in Trace Element Metabolism and Function: Role of Metallothionein in Copper and Zinc Metabolism. J. Nutr. 119:1062-1070

RUST, S. R. 1995: Effects of zinc methionine and grain processing on performance of growing fattening steers. J. Anim. Sci. 61 (Suppl.1):482 (Abstract)

SAS Institute. 1989. SAS User Guide, Version 6, fourth ed. volume 1 and 2, Carry, NC, SAS Institute Inc.

SMITH, J. C. Jr., BUTRIMOVIT, G. P., PURDY, W. C. 1979: Direct measurement of zinc in plasma by atomic absorption spectroscopy. Clin. Chem. 25:1487-1491

SWINKELS, J. W., KORNEGAJY, E. T., WEBB, K. E. Jr., LINDEMANN, M. D. 1991: Comparison of inorganic and organic zinc chelate in zinc depleted and repleted pigs. J. Anim. Sci. 69 (Suppl, 1):358 (Abstract)

WEDEKIND, K. J., HORTIN, A. E., BAKER, D. H. 1992: Methodology for Assessing zinc bioavailability: efficacy estimates for zinc-methionine, zinc sulfate, and zinc oxide. J. Anim. Sci. 70:178-187

WEDEKIND, K. J., LEWIS, A. J., GIESEMANN, M. A., MILLER, P. S. 1994: Bioavailability of zinc from inorganic and organic source for pigs fed corn-soybean meal diets. J. Anim. Sci. 72:2681-2689

ŽURIĆ, M., STANKOVIĆ, H. 1991: AST, ALT and GGT activity in the blood serum of intensive breeding pigs in relation to pathohistological liver problems. (In Croatian). Veterinarska stanica 22:195-204

Address for correspondence:

Prof. Dr. Vlatko Rupić

Faculty of Agriculture

University of Zagreb

Svetošimunska c. 25

10000 Zagreb

Croatia

Phone: 38512392823

Fax: 38512393947 
Plate II.

Rupić, V. et al.: Influence of... pp. 75-85
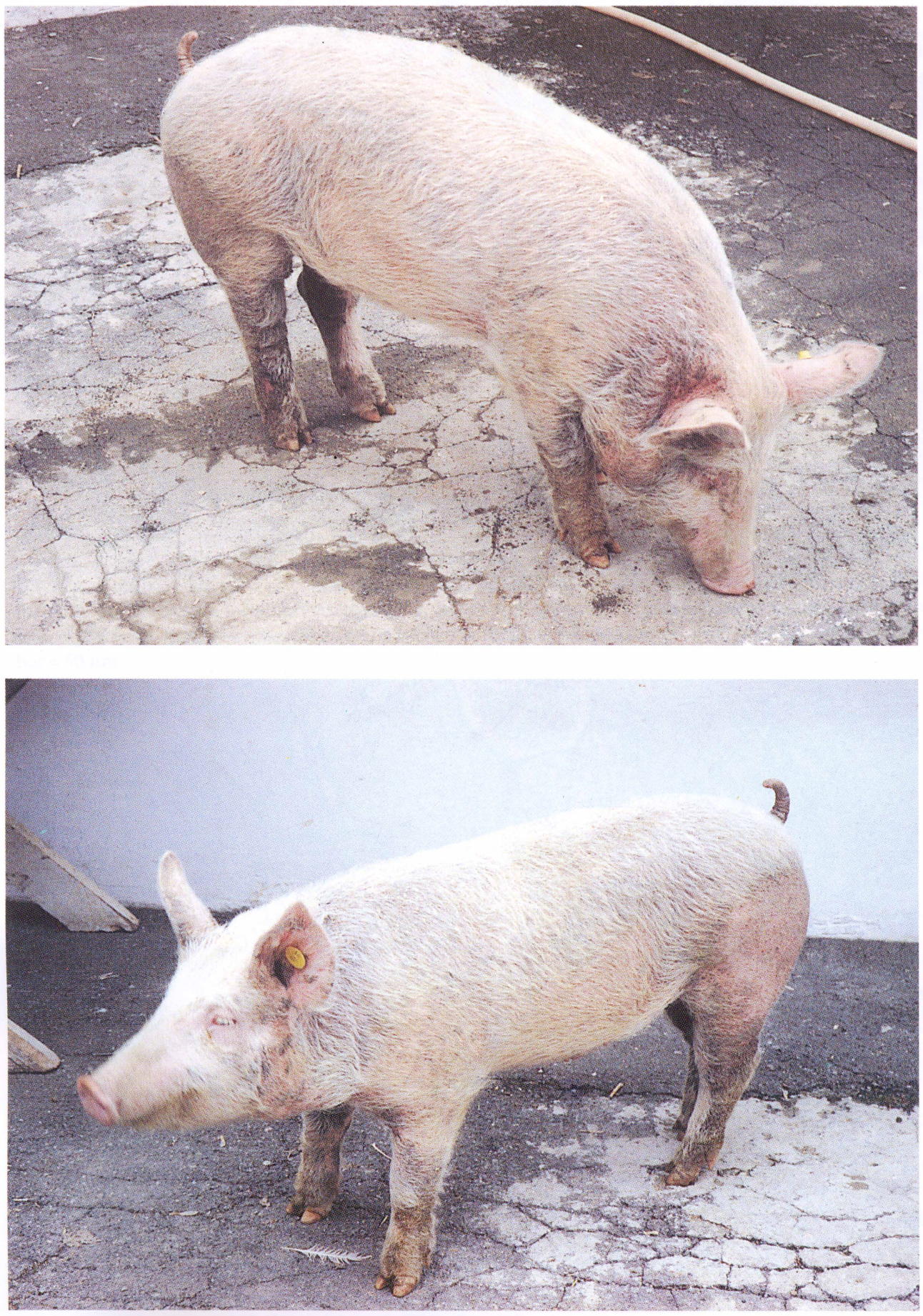

Fig. 1. and 2. Typical parakeratotic changes on the skin of head, neck, front and back legs. 